\title{
Effect of temperature on photosynthesis, oxygen consumption and sulfide production in an extremely hypersaline cyanobacterial mat
}

\author{
Raeid M. M. Abed ${ }^{1, *}$, Lubos Polerecky ${ }^{1}$, Mohammad Al Najjar ${ }^{2}$, Dirk de Beer ${ }^{1}$ \\ ${ }^{1}$ Max Planck Institute for Marine Microbiology, Celsiusstraße 1, 28359 Bremen, Germany \\ ${ }^{2}$ Biology Department, Faculty of Science, United Arab Emirates University, PO Box 17551, Al Ain, UAE
}

\begin{abstract}
We used microsensors to study short-term temperature effects on gross photosynthesis, oxygen consumption and sulfate reduction in an extremely hypersaline (salinity $200 \%$ ) cyanobacterial mat. In situ, the mat surface can reach high temperatures (ca. $50^{\circ} \mathrm{C}$ in summer), and experiences daily temperature fluctuations due to tidal inundation. A mat sample was incubated in the laboratory at $25,35,45,50$ and $60^{\circ} \mathrm{C}$. Areal rates of gross and net photosynthesis increased with increasing temperature, and maximum rates were detected at $45^{\circ} \mathrm{C}$. The photosynthetic zone (i.e. the depth zone in which oxygenic photosynthesis was detectable by the light-dark shift method) decreased from 3 to $1.75 \mathrm{~mm}$ with increasing temperature. Above $50^{\circ} \mathrm{C}$, photosynthesis was completely inhibited, probably due to high sulfide concentrations. This inhibition was confirmed by the $\mathrm{pH}$ profiles, where the peak in the top 2 to $4 \mathrm{~mm}$ at 25 to $45^{\circ} \mathrm{C}$ disappeared at 50 to $60^{\circ} \mathrm{C}$. Between 25 and $45^{\circ} \mathrm{C}$, areal oxygen consumption rates in the light did not change significantly but showed a decreasing trend in the photosynthetic zone, suggesting a decoupling between photosynthesis and oxygen consumption in the light. In both the light and dark, sulfide production was strongly enhanced by increasing temperature to a maximum flux at $50^{\circ} \mathrm{C}$, above which it became inhibited. At 50 to $60^{\circ} \mathrm{C}$, the sulfide produced could not be completely removed by sulfide oxidation, resulting in sulfide leakage to the overlying water. Our data demonstrate that these mat ecosystems are well adapted to high ambient temperatures. Photosynthesis, oxygen consumption in the light and sulfide production are differentially controlled by temperature. However, the individual processes in this complex community are not only directly controlled by temperature, but also by the temperaturedependent response of other processes.
\end{abstract}

KEY WORDS: Cyanobacterial mats · Temperature · Microsensors · Arabian Gulf $\cdot$ Photosynthesis · Oxygen consumption

Resale or republication not permitted without written consent of the publisher

\section{INTRODUCTION}

Temperature determines the composition of microbial communities and the rates of the associated metabolic processes. Cyanobacterial mats are found in diverse habitats including those where temperature reaches extreme values, e.g. permanently cold Antarctic lakes (Buffan-Dubau et al. 2001) or very hot springs and deserts (Golubic 1991, Al-Thukair \& Al-Hinai 1993, Ward et al. 1997, 1998, Garcia-Pichel \& Pringault 2001). Short-term temperature effects on bacterial pro- cesses (such as oxygen consumption, photosynthesis and sulfate reduction) of microbial mats have been elucidated in a number of studies employing microsensors (Epping \& Kühl 2000, Wieland \& Kühl 2000a,b, Pringault et al. 2001). Both psychrophilic (temperature range 0 to $15^{\circ} \mathrm{C}$ ) (Pringault et al. 2001) and mesophilic (temperature range 15 to $40^{\circ} \mathrm{C}$ ) hypersaline mats (Epping \& Kühl 2000, Wieland \& Kühl 2000a) showed a tight coupling of oxygen consumption in the light and photosynthesis at all temperatures and stimulation of sulfate reduction rates. The effects of temperature on 
the physiology of microbial mats that experience temperatures exceeding $40^{\circ} \mathrm{C}$ were previously unknown.

It has been postulated that the temperature optima for the metabolism of individual microorganisms do not necessarily represent their optima under field conditions, because the physiology of individuals in complex communities is largely influenced by, if not derived from, the activity of other community members (van den Ende \& van Gemerden 1994). Therefore, it is yet unclear whether bacteria in such communities exhibit their thermal adaptation to variations in temperatures under in situ conditions. Since microbial mats are composed of physiologically different bacterial groups (photoautotrophic, photoheterotrophic, chemoautotrophic and heterotrophic) (van Gemerden 1993), that exhibit most, if not all, biogeochemical processes that exist in aquatic ecosystems (Canfield \& Des Marais 1993), their response to environmental stimuli may be rather complex. Respiratory activity of heterotrophic bacteria is dependent on cyanobacterial photosynthesis and both processes were found to be tightly coupled (Glud et al. 1992, Canfield \& Des Marais 1993, Wieland \& Kühl 2000a). Aerobic heterotrophic bacteria compete with sulfur-oxidizing bacteria for oxygen (van den Ende et al. 1996) and compete with sulfate-reducing bacteria (SRB) for organic compounds produced within mats (Jørgensen et al. 1992). SRB produce sulfide that inhibits photosynthesis but can be re-oxidized to sulfate by both colorless and purple sulfur bacteria (van Gemerden 1993). In such tight interactions, shifts in a single process directly influence other processes. Consequently, studying temperature effects on the functioning of microbial mats requires a comprehensive in situ approach in which all significant processes are directly measured.

In this study, we investigated the short-term effects of temperature on the microbial metabolic activities of an extremely hypersaline cyanobacterial mat thriving under the high temperature conditions of the coastal intertidal flats of the Arabian Gulf. These mats are ideal model ecosystems for studying the effects of high temperatures on various biogeochemical cycles. Temperature in this region is typically between 35 and $50^{\circ} \mathrm{C}$ in summer and between 15 and $35^{\circ} \mathrm{C}$ in winter. Furthermore, large daily temperature variations $\left(15^{\circ} \mathrm{C}\right)$ occur due to tidal regime. Microsensors for $\mathrm{O}_{2}, \mathrm{pH}$ and $\mathrm{H}_{2} \mathrm{~S}$ were used and depth profiling was performed at different temperatures in the light and in the dark.

Our goals were to (1) obtain insights into the biogeochemistry of these mats and their adaptation to high temperatures and (2) compare our data to those obtained from similar studies on hypersaline mats from mesophilic and psychrophilic environments. We hypothesized that the different metabolic processes in microbial mats that experience high temperatures $\left(>40^{\circ} \mathrm{C}\right)$ are also balanced at different temperatures in a fashion similar to that of meso- and psychrophilic mats.

\section{MATERIALS AND METHODS}

Study site. A microbial mat was collected from the intertidal coastal flats (Sabkha) of Abu Dhabi, United Arab Emirates, in December 2004. On these flats, such mats are exposed to continuous flushing by tidal seawater, leading to periods of dryness and wetness and causing the formation of channels throughout the entire mat system. The tidal regime and the high evaporation rate result in daily salinity changes in the overlying water ranging from 60 to $200 \%$ or more. The mat sample used in this study was collected from the channels while covered with seawater of $200 \%$ salinity and a temperature of $30^{\circ} \mathrm{C}$.

Experimental setup. A mat sample $(10 \times 8 \times 4 \mathrm{~cm})$ was placed in a glass aquarium, covered with filtered in situ seawater and left for $24 \mathrm{~h}$ to acclimate to laboratory conditions. The in situ salinity of $200 \%$ was maintained constant throughout the experiment. The seawater was continuously bubbled with air. The temperature was controlled by a thermostatic water bath (Julabo, F32-HC) connected to the aquarium by a heat exchanging coil. The mat was illuminated in $12 \mathrm{~h}: 12 \mathrm{~h}$ light:dark cycles using a fiber-optic light source (Schott, KL 1500) with light intensity adjusted to $500 \mu \mathrm{mol}$ photons $\mathrm{m}^{-2} \mathrm{~s}^{-1}$. Incubations at each of the investigated temperatures $\left(25,35,45,50\right.$ and $\left.60^{\circ} \mathrm{C}\right)$ lasted for $24 \mathrm{~h}$.

Microsensor setup. Steady-state $\mathrm{O}_{2}, \mathrm{pH}$ and $\mathrm{H}_{2} \mathrm{~S}$ microprofiles were measured at each incubation temperature in $200 \mu \mathrm{m}$ steps down to $6 \mathrm{~mm}$ inside the mat. At a given temperature, dark profiles were measured overnight whereas the light profiles were measured after 2 to $3 \mathrm{~h}$ illumination. Microprofiles were measured using an automated setup controlled by a computer. Microsensor positioning with $1 \mu \mathrm{m}$ precision was facilitated by a VT-80 linear positioner (Micos) equipped with a DC motor (Faulhaber). The $\mathrm{O}_{2}$ and $\mathrm{H}_{2} \mathrm{~S}$ microsensors were connected to fast-responding picoampermeters while the $\mathrm{pH}$ microsensor was connected to a millivoltmeter. The signals were collected using a data acquisition card (DAQCard-AI-16XE-50, National Instruments). The sensors were positioned at the mat surface with the help of a dissection microscope (SV6, Zeiss).

Microsensor measurements. Oxygen concentrations and volumetric gross photosynthesis: Fast-responding Clark-type $\mathrm{O}_{2}$ microsensors with a guard cathode were used (Revsbech 1989). The applied $\mathrm{O}_{2}$ sensors had tip diameters $\sim 30 \mu \mathrm{m}$, a stirring sensitivity $<2 \%$, and a $90 \%$ response time, $t_{90},<0.5$ s. A 2 -point linear calibration at each incubation temperature was obtained 
from the readings taken in the anoxic layer of the mat and in the overlying aerated seawater (Revsbech \& Jørgensen 1986, Revsbech 1989). Oxygen solubility at the experimental temperature and salinity (200\%) was calculated according to Sherwood et al. (1991).

Gross photosynthesis (GP) was measured employing the light-dark shift method (Revsbech \& Jørgensen 1983) at $250 \mu \mathrm{m}$ depth intervals. The mat was first illuminated until the oxygen distribution reached steady state. Subsequently, the mat was darkened for 1 to $3 \mathrm{~s}$ and the volumetric rate $\left(\mathrm{mol} \mathrm{O} \mathrm{O}^{-3} \mathrm{~s}^{-1}\right)$ of GP was calculated from the slope of the linear decrease of oxygen concentration measured by the microsensor during the dark period. Volumetric oxygen consumption rates during light (OCL) exposure were determined by subtracting the net photosynthesis (NP) from the GP rate. NP was determined by fitting the steady-state oxygen profile at a vertical resolution of $400 \mu \mathrm{m}$ (except at around the depth of $2 \mathrm{~mm}$ at 25 and $35^{\circ} \mathrm{C}$, when the vertical resolution of $200 \mu \mathrm{m}$ was used to capture the sharp dip) with a diffusion model (Berg et al. 1998). The calculated NP rates were interpolated to those depths where GP was measured. The diffusion coefficient in the mat $\left(D_{\mathrm{m}}\right)$ was taken as $80 \%$ of that in the overlying seawater $\left(D_{0}\right)$, which was corrected for temperature and salinity (Wieland et al. 2001, Grötzschel et al. 2002).

Areal rates: Areal rates $\left(\mathrm{mol} \mathrm{O}_{2} \mathrm{~m}^{-2} \mathrm{~s}^{-1}\right)$ of $\mathrm{GP}$ were calculated by integrating the volumetric GP rates over the depth of the photosynthetic zone. The areal NP rate of the mat was calculated as the $\mathrm{O}_{2}$ flux inside the mat at the surface using Fick's law of diffusion (Jørgensen \& Revsbech 1985, Jensen \& Revsbech 1989) and the oxygen $D_{\mathrm{m}}$. This was to avoid possible complications associated with compression of the diffusive boundary layer (DBL) by the microsensor (Glud et al. 1994). The flux of 3 to 5 profiles at each temperature was calculated from 2 points at 25 and $35^{\circ} \mathrm{C}$ and 3 points at $45^{\circ} \mathrm{C}$, and the average NP rate was taken. Areal rates of OCL were calculated by subtracting the areal NP from the areal GP rate. The standard deviation of OCL was calculated by summing the standard deviations of GP and NP. Areal rates of oxygen consumption in the dark (DR) were obtained by calculating the flux at the mat surface from the profiles measured in the dark. Alternatively, areal NP rates were calculated by integrating the volumetric NP rates obtained by the fits (see preceding subsection), giving the same results.

The photosynthetic zone was determined as the depth zone in which oxygenic photosynthesis was detectable by the light-dark shift method. To compare the oxygen consumption in the photosynthetic and non-photosynthetic zone, areal OCL rates were calculated by integrating the volumetric oxygen consumption rates (see preceding subsection) over the respective depth intervals. The areal oxygen consumption rate in the non-photosynthetic zone was alternatively calculated as the diffusive flux $(J)$ at the interface between the photosynthetic and non-photosynthetic depth zones $\left(J=D_{\mathrm{m}} \times \mathrm{d} C(z) / \mathrm{d} z ; D_{\mathrm{m}}=0.8 D_{0}\right)$; where $\mathrm{d} C(z) / \mathrm{d} z$ is the oxygen concentration gradient at depth $z$, giving the same result.

pH measurements: For $\mathrm{pH}$ measurements, potentiometric glass $\mathrm{pH}$ microsensors with tip diameters of 20 to $30 \mu \mathrm{m}$ were used (Revsbech \& Jørgensen 1986). The $\mathrm{pH}$-sensitive tip of the microsensor was shorter than $100 \mu \mathrm{m}$. Calibration of the microsensor was performed at $25^{\circ} \mathrm{C}$ using standard solutions of $\mathrm{pH} 4,7.0$ and 9.21 (Mettler). The calibration values were corrected for the various experimental incubation temperatures assuming that $\mathrm{pH}$ decreases by 0.0114 Units with every $1^{\circ} \mathrm{C}$ increase in temperature (Grasshoff 1983).

Sulfide measurements: Dissolved hydrogen sulfide was measured using a $\mathrm{H}_{2} \mathrm{~S}$ microsensor with a tip diameter of $<20 \mu \mathrm{m}$ (Kühl et al. 1998). The sensors were coated with black enamel paint to minimize the influence of light on the signal. Calibration was done in a plexiglass calibration chamber closed with a rubber cap with 2 holes, one for the microsensor, the other for addition of the $\mathrm{Na}_{2} \mathrm{~S}$ stock solution. The chamber was filled with $100 \mathrm{ml}$ phosphate buffer (200 mM, $\mathrm{pH}$ 7.5) purged with nitrogen gas. Defined volumes of $\mathrm{Na}_{2} \mathrm{~S}$ stock solution were added to the anoxic buffer and thoroughly mixed. After each addition, the picoampermeter reading was recorded and a subsample was removed and immediately fixed in $2 \%$ zinc acetate. These samples were stored at $4{ }^{\circ} \mathrm{C}$ for later analysis. The total sulfide $\left(\left[\mathrm{S}^{2-}{ }_{\text {tot }}\right]=\left[\mathrm{H}_{2} \mathrm{~S}\right]+\left[\mathrm{HS}^{-}\right]+\left[\mathrm{S}^{2-}\right]\right)$ in the collected calibration subsamples was determined with Cline's colorimetrical total sulfide determination method (Cline 1969, Fonselius 1983). The $\mathrm{H}_{2} \mathrm{~S}$ concentrations were obtained as described by Jeroschewski et al. (1996) and Millero et al. (1988). The total sulfide concentrations at each depth were calculated from the local $\mathrm{H}_{2} \mathrm{~S}$ concentrations and $\mathrm{pH}$ values.

Determination of stoichiometry of aerobic sulfide oxidation: To estimate whether the biological oxidation of sulfide by oxygen could be balanced, we considered the following reactions:

$$
\begin{gathered}
\mathrm{H}_{2} \mathrm{~S}+0.5 \mathrm{O}_{2} \rightarrow \mathrm{S}^{0}+\mathrm{H}_{2} \mathrm{O} \\
\mathrm{H}_{2} \mathrm{~S}+2 \mathrm{O}_{2} \rightarrow \mathrm{SO}_{4}^{2-}+2 \mathrm{H}^{+}
\end{gathered}
$$

Oxygen and sulfide volumetric consumption rates (OCR and SCR, respectively) were determined by fitting the respective steady-state profiles by a diffusion model (Berg et al. 1998, Wieland \& Kühl 2000a). For simplicity, other intermediates like thiosulfate were not considered. If the OCR was less than 0.5 times the $\mathrm{SCR}$, aerobic sulfide oxidation was assumed incomplete; when OCR was 2 times SCR or higher, complete aerobic sulfide oxidation was considered possible. 


\section{RESULTS}

The mat studied was compact, with typical lamination that was macroscopically visible (Fig. 1). The mat surface was homogenous, smooth, very gelatinous and reddish in color. Microscopic examination of the top $2 \mathrm{~mm}$ showed that the top $1 \mathrm{~mm}$ was dominated by the typical mat-building cyanobacterium Microcoleus chthonoplastes. Below this layer was a layer dominated by unicellular cyanobacteria from the Halothece spp. group. During the experiment and at temperatures between 25 and $45^{\circ} \mathrm{C}$, the mat showed slight darkening of the surface due to upward migration of cyanobacteria, as observed microscopically. At temperatures above $50^{\circ} \mathrm{C}$, the mat surface became rough with irregular whitish spots. Microscopy revealed that these spots contained $M$. chthonoplastes and sulfurcontaining Beggiatoa-like bacteria.

\section{Oxygen, pH and sulfide profiles}

The oxygen, $\mathrm{pH}$ and sulfide profiles were strongly influenced by temperature (Fig. 2). At 25 to $35^{\circ} \mathrm{C}$ in the light, 2 oxygen peaks were observed representing 2 photosynthetically active zones (Fig. 2, left-hand panels). At $45^{\circ} \mathrm{C}$ the peak in the deeper zone disappeared, and at higher temperatures both peaks disappeared and NP ceased. The GP patterns were in agreement: at lower temperatures 2 photosynthetic maxima were found, at $45^{\circ} \mathrm{C}$ only 1 , and at higher temperatures GP ceased. Oxygen penetration in the light and the thickness of the photosynthetic layer showed a decreasing trend with increasing temperature (Table 1). In the dark incubations, oxygen penetrated $<1 \mathrm{~mm}$ at all temperatures, and no clear trend was visible. At 50 and $60^{\circ} \mathrm{C}$ the dark and light profiles were similar.

The photosynthesis patterns were reflected in the light $\mathrm{pH}$ profiles (Fig. 2, middle panels). The distinct

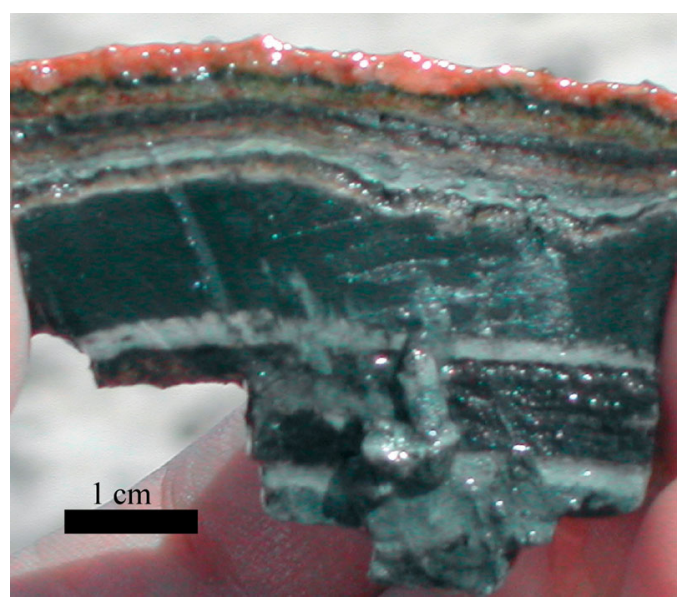

Fig. 1. Laminated microbial mat used in present study

peak observed at lower temperatures gradually decreased at higher temperatures, when photosynthesis stopped. At $6 \mathrm{~mm}$ depth, a remarkable decrease in $\mathrm{pH}$ with increasing temperature was observed, dropping from 7.6 at $25^{\circ} \mathrm{C}$ to 6.1 at $50^{\circ} \mathrm{C}$. Also, in the dark a gradual decrease in $\mathrm{pH}$ was observed. The $\mathrm{pH}$ in the deeper zones decreased with increasing temperature from 6.7 at $25^{\circ} \mathrm{C}$ to 6.3 at $60^{\circ} \mathrm{C}$.

In the dark, the sulfide profiles showed a gradual increase in sulfide concentrations that became more pronounced at higher temperatures (Fig. 2, right-hand panels). The profiles steepened with increasing temperature up to $50^{\circ} \mathrm{C}$, above which the sulfide concentrations were strongly reduced. Illumination of the mats resulted in a decrease in the sulfide concentrations, and the sulfidic zone shifted downwards, at lower temperatures. However, at temperatures of 50 and $60^{\circ} \mathrm{C}$, when photosynthesis ceased, the position of the sulfidic zone was not influenced by light. Sulfide concentrations showed an increasing trend up to $50^{\circ} \mathrm{C}$, but crashed at $60^{\circ} \mathrm{C}$.

Table 1. Rates of microbial processes and parameters characterizing the microenvironment of the studied hypersaline (salinity $200 \%$ ) cyanobacterial mat as a function of temperature. - : unavailable values due to the inhibition of photosynthesis at these 2 temperatures

\begin{tabular}{|c|c|c|c|c|c|c|}
\hline Process/parameter & Unit & $25^{\circ} \mathrm{C}$ & $35^{\circ} \mathrm{C}$ & $45^{\circ} \mathrm{C}$ & $50^{\circ} \mathrm{C}$ & $60^{\circ} \mathrm{C}$ \\
\hline $\mathrm{O}_{2}$ penetration (light) & $\mathrm{mm}$ & 3.00 & 2.75 & 1.75 & 0.40 & 0.80 \\
\hline $\mathrm{O}_{2}$ penetration (dark) & $\mathrm{mm}$ & 0.60 & 0.80 & 0.80 & 0.40 & 1.00 \\
\hline Maximum $\mathrm{O}_{2}$ concentration (light) & $\mu \mathrm{M}$ & 344 & 359 & 400 & - & - \\
\hline Thickness of photosynthetic zone & $\mathrm{mm}$ & 3.00 & 2.75 & 1.75 & - & - \\
\hline Areal dark oxygen consumption & $\mathrm{nmol} \mathrm{cm}{ }^{-2} \mathrm{~s}^{-1}$ & 0.014 & 0.018 & 0.015 & 0.017 & 0.008 \\
\hline Areal light oxygen consumption & $\mathrm{nmol} \mathrm{cm} \mathrm{c}^{-2} \mathrm{~s}^{-1}$ & 0.066 & 0.067 & 0.060 & 0.027 & 0.019 \\
\hline Oxygen consumption in photic zone & $\mathrm{nmol} \mathrm{cm}{ }^{-2} \mathrm{~s}^{-1}$ & 0.027 & 0.021 & 0.001 & - & - \\
\hline Oxygen consumption in aphotic zone & $\mathrm{nmol} \mathrm{cm}{ }^{-2} \mathrm{~s}^{-1}$ & 0.038 & 0.045 & 0.058 & - & - \\
\hline Areal gross photosynthesis & $\mathrm{nmol} \mathrm{cm}{ }^{-2} \mathrm{~s}^{-1}$ & 0.101 & 0.129 & 0.178 & 0.0 & 0.0 \\
\hline Areal net photosynthesis & $\mathrm{nmol} \mathrm{cm}{ }^{-2} \mathrm{~s}^{-1}$ & 0.035 & 0.061 & 0.117 & - & - \\
\hline Net areal photosynthesis of photic zone & $\mathrm{nmol} \mathrm{cm}{ }^{-2} \mathrm{~s}^{-1}$ & 0.030 & 0.070 & 0.157 & - & - \\
\hline Maximum light sulfide concentration & $\mu \mathrm{M}$ & 646 & 714 & 5395 & 13560 & 1253 \\
\hline Maximum dark sulfide concentration & $\mu \mathrm{M}$ & 2795 & 1849 & 5740 & 10337 & 2736 \\
\hline
\end{tabular}




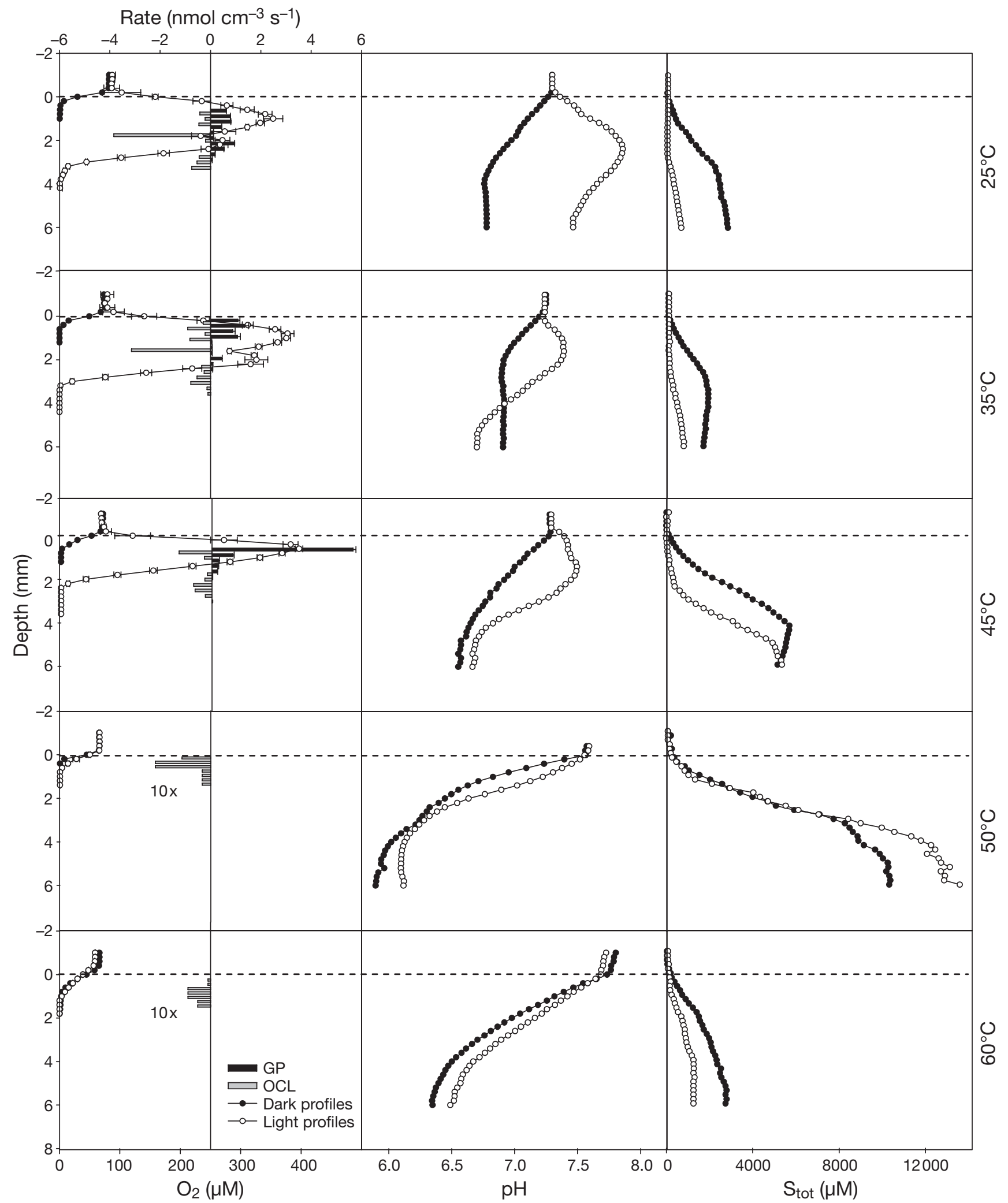

Fig. 2. Mean depth profiles of $\mathrm{O}_{2}, \mathrm{pH}$ and total sulfide $\left(\mathrm{S}_{\text {tot }}\right)$ in the light and in the dark at different temperatures. Black bars: average rates $(n=3)$ of volumetric gross photosynthesis $(\mathrm{GP})$; gray bars: average rates of volumetric light oxygen consumption (OCL); $\mathrm{SD}\left(\mathrm{n}=3\right.$ measurements) are indicated by error bars for $\mathrm{O}_{2}$ profiles. Volumetric OCL rates at 50 and $60^{\circ} \mathrm{C}$ multiplied by 10 for clarity 


\section{Areal rates of photosynthesis and oxygen consumption}

The areal rates of the NP, GP, OCL and DR are summarized in Fig. 3 \& Table 1. Areal GP rates increased with increasing temperature from 25 to $45^{\circ} \mathrm{C}$ and collapsed at higher temperatures. Maximum GP was at $45^{\circ} \mathrm{C}$. NP also increased between 25 and $45^{\circ} \mathrm{C}$, resulting in slight changes in the OCL. The areal OCL rates decreased at higher temperatures, where photosynthesis ceased. Areal oxygen consumption rates in the photosynthetic zone showed a decreasing trend with increasing temperature, while the oxygen consumption rate in the non-photosynthetic zone showed an increasing trend. The temperature dependence of DR was not as pronounced as for OCL.

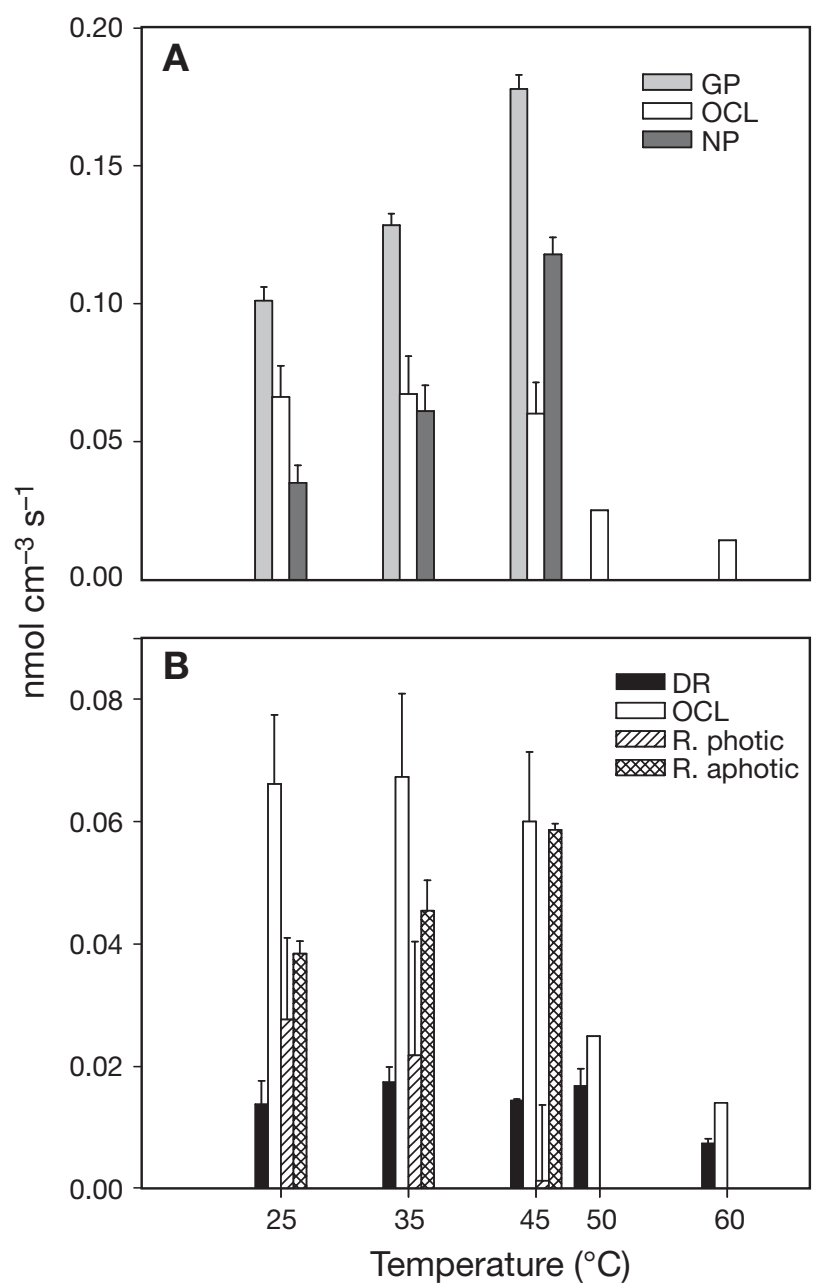

Fig. 3. Temperature dependence of areal rates $(+\mathrm{SD})$ of (A) gross photosynthesis (GP), net photosynthesis (NP) and light oxygen consumption (OCL), (B) dark oxygen consumption (DR) and OCL divided into oxygen consumption in photosynthetic (R. photic) and non-photosynthetic (R. aphotic) zones

\section{Oxygen and sulfide budgets}

In the zone where oxygen and sulfide overlap, the average volumetric OCR were in most cases between 0.5 and 2 times higher than SCR (Fig. 4A). The only exceptions were under light conditions at 50 and $60^{\circ} \mathrm{C}$ and in the dark at $60^{\circ} \mathrm{C}$, when SCR $>2$ OCR (Fig. 4A).

Under light conditions at 25 and $35^{\circ} \mathrm{C}$, the maximum oxygen flux, $J_{\max }\left(\mathrm{O}_{2}\right)$, was (with a very good precision) twice the maximum total sulfide flux, $J_{\max }\left(\mathrm{S}_{\text {tot }}\right)$ (Fig. 4B). The same was true for the average oxygen and sulfide consumption rates in the overlapping region (Fig. 4A). The maxima of oxygen and sulfide fluxes occurred at the top and bottom of the overlapping region, respectively. Under dark conditions at 25 and $35^{\circ} \mathrm{C}$, $J_{\max }\left(\mathrm{S}_{\text {tot }}\right)$ exceeded $J_{\max }\left(\mathrm{O}_{2}\right)$ (Fig. $4 \mathrm{C}$ ). Whereas the oxygen flux reached its maximum at the mat surface, maximum sulfide flux was observed at 2 to $3 \mathrm{~mm}$, which is considerably deeper than the corresponding oxygen penetration depth $(0.6 \mathrm{~mm})$. The sulfide flux decreased by 40 to $60 \%$ before the oxygen was reached. In the overlapping region, average sulfide and oxygen consumption rates were very close.

At $45^{\circ} \mathrm{C}$ and higher, the $J_{\max }\left(\mathrm{S}_{\text {tot }}\right) / J_{\max }\left(\mathrm{O}_{2}\right)$ ratio was far above from unity both in the light and in the dark (Fig. $4 \mathrm{C}, \mathrm{D}$ ). In the overlapping region at $45^{\circ} \mathrm{C}$, average sulfide and oxygen consumption rates were similar. In the dark, net sulfide consumption started at a depth where oxygen penetrated during the light (Fig. 2). The sulfide flux into the oxic zone was 4 to 10 times higher than $J_{\max }\left(\mathrm{O}_{2}\right)$, leading to a leakage of sulfide into the overlying water in the dark at temperatures $\geq 45^{\circ} \mathrm{C}$.

\section{DISCUSSION}

This study provides insights into the biogeochemistry of an extremely hypersaline microbial mat and the role of temperature in the regulation of various metabolic processes. Temperature not only affected the rates of photosynthesis, oxygen consumption in the light and sulfide production, but also influenced the interactions among these processes.

\section{Direct and indirect temperature effects on photosynthesis}

Temperature had a clear effect on the rates of GP and NP as well as on the thickness of the photosynthetic zone. GP showed a maximum rate at $45^{\circ} \mathrm{C}$, above which it collapsed. The increase in GP at $45^{\circ} \mathrm{C}$ can be attributed to direct temperature effects on the enzymes involved in $\mathrm{CO}_{2}$ fixation ( $\mathrm{Li}$ et al. 1984, 
A
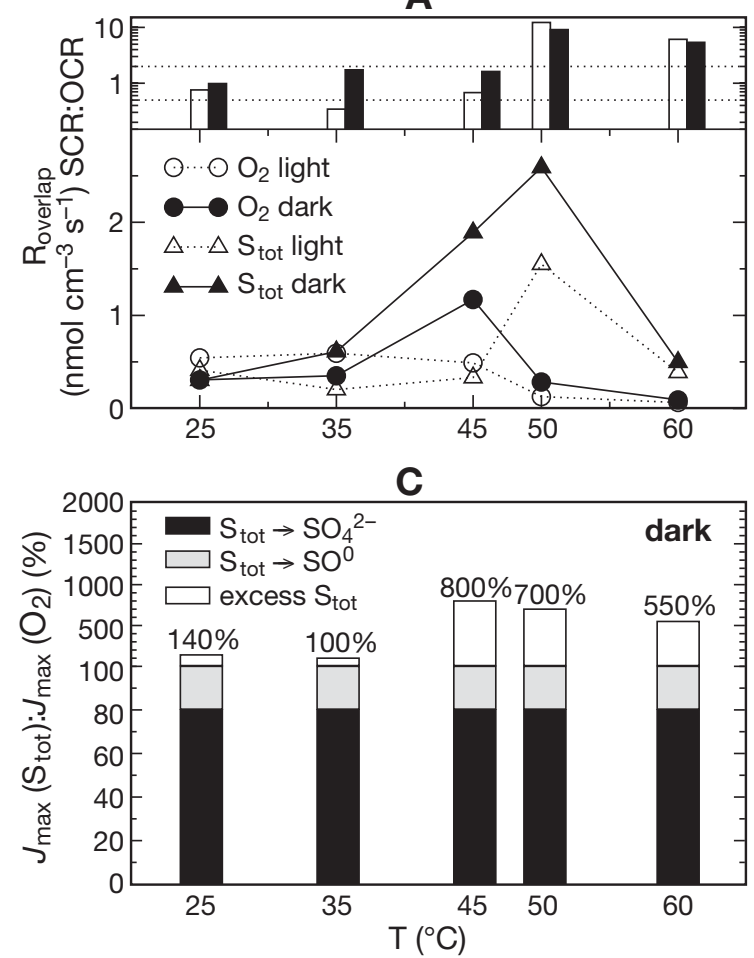

B
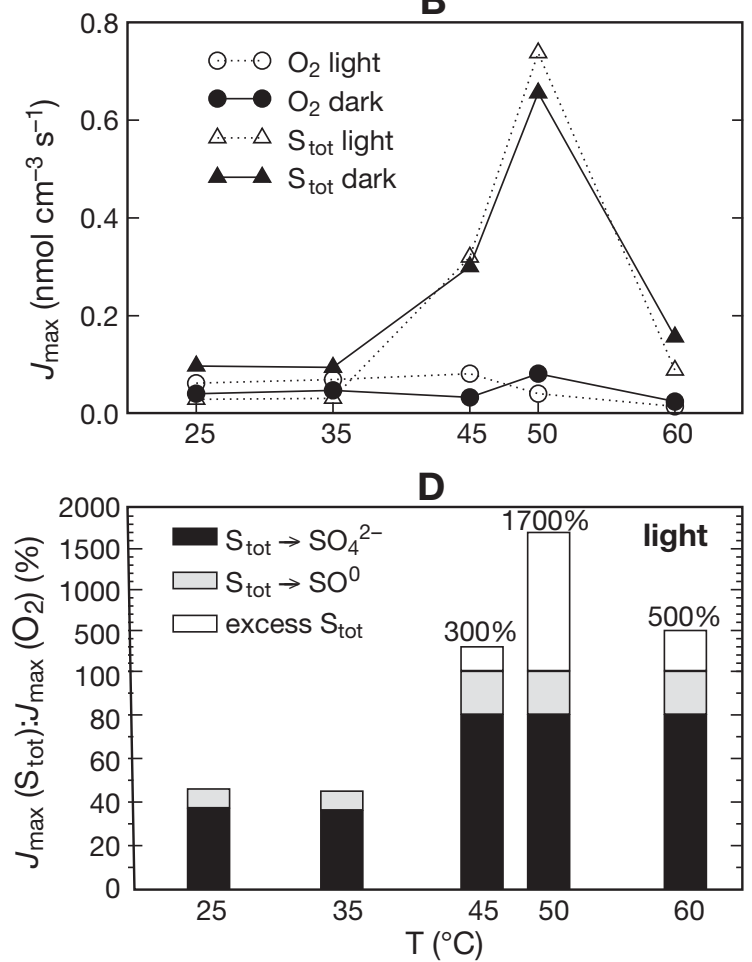

Fig. 4. (A) Volumetric oxygen (OCR) and sulfide (SCR) consumption rates (bottom) and the ratio between the 2 rates ( $\mathrm{R}_{\text {overlap }}$ top) in the oxygen-sulfide overlapping zone. (B) Maximum fluxes $\left(J_{\max }\right)$ of $\mathrm{O}_{2}$ and total sulfide $\left(\mathrm{S}_{\text {tot }}\right)$ in mat as a function of temperature. (C,D) Ratios between maximum sulfide flux and maximum oxygen flux shown separately for light (C) and dark (D); sulfide flux was divided into 2 parts based on equal probability of sulfide being oxidized into sulfate and elemental sulfur. High values for excess $\mathrm{S}_{\text {tot }}$ flux indicate that removal of sulfide was limited by oxygen availability; note different scales below and above $100 \%$ line in (C) and (D)

Sukenik et al. 1987, Raven \& Geider 1988, Davison 1991) and on the diffusion of $\mathrm{CO}_{2} / \mathrm{HCO}_{3}{ }^{-}$and nutrients across the plasmalemma and/or chloroplast membrane(s). The possible fusion of the 2 cyanobacterial populations observed at lower temperatures (Fig. 2) could not account for this increase, as the sum of GP rates of both populations at 25 or $35^{\circ} \mathrm{C}$ was still lower than that at $45^{\circ} \mathrm{C}$. The cyanobacteria in the deeper layer died due to high sulfide concentrations and did not migrate upward since this layer was dominated by Halothece-like cyanobacteria, among which motility is not common.

The inhibition of GP at $50^{\circ} \mathrm{C}$ was due to the inhibition of Photosystem II (PSII) either by temperature or by sulfide, which reached its maximum at this temperature. Sulfide was shown to inhibit PSII, which is responsible for the generation of electrons (Castenholz 1976), and to block the electron transport chain by reacting to cytochromes, heme-proteins and metal proteins (Cohen et al. 1986). In a separate experiment, the phototrophs in this mat photosynthesized at temperatures up to $60^{\circ} \mathrm{C}$, but only when the photosynthetic layer was separated from the sulfide-producing deeper layers. This indicates that photosynthesis was most likely inhibited by the high sulfide concentrations rather than by temperature. As photosynthesis did not recover at $60^{\circ} \mathrm{C}$ (at which temperature sulfide concentrations were low), sulfide inhibition of photosynthesis seems to have been irreversible.

The migration of Microcoleus chthonoplastes to the mat surface at $50^{\circ} \mathrm{C}$ was stimulated by the upward diffusion of sulfide. Previous studies showed this cyanobacterium to possess a versatile metabolism and to tolerate conditions of high sulfide (Jørgensen et al. 1983, Cohen et al. 1986, Stal 1991). Thus, M. chthonoplastes probably switched from oxygenic photosynthesis to anoxygenic photosynthesis at higher temperatures, by using alternatively sulfide as an electron donor.

\section{Uncoupling of photosynthesis and oxygen consumption in light}

The most unexpected finding in this study was the uncoupling between OCL and GP with increasing temperature. All previous studies showed that these 2 processes remained coupled, under all environmental 
conditions (Canfield \& Des Marais 1993, Kühl et al. 1996, Epping \& Kühl 2000, Wieland \& Kühl 2000a, Pringault et al. 2001). The effect of temperature on the measured areal GP and NP was statistically tested using ANOVA. The increase in both rates between 25 and $45^{\circ} \mathrm{C}$ was statistically significant $\left(\mathrm{p}=3 \times 10^{-6}\right.$ for GP and $\mathrm{p}=10^{-5}$ for NP). Pair-wise Tukey post-hoc tests further revealed that GP and NP significantly increased in both temperature intervals (from 25 to $35^{\circ} \mathrm{C}$ and 35 to $\left.45^{\circ} \mathrm{C}, \mathrm{p} \leq 0.008\right)$. On the other hand, the areal OCL rates, whose standard deviation was calculated as the sum of the standard deviations of GP and $N P$, did not significantly differ (Students $t$-test: $p>0.5$ ). This indicates uncoupling between GP and OCL in response to temperature. The decreasing and the increasing trends of oxygen consumption in the light were consistently observed in the photosynthetic and non-photosynthetic zones, respectively, although these changes were not statistically significant.

The decrease in OCL in the photosynthetic zone at $45^{\circ} \mathrm{C}$ could be due to the inhibition of the strongly respiring bacterial layer between the 2 cyanobacterial layers at 25 and $35^{\circ} \mathrm{C}$ (Fig. 2). Temperature might have inhibited respiration of these bacteria by directly influencing their membrane composition and enzyme properties (Thamdrup et al. 1998). Another explanation of this inhibition could be the dramatic increase in SRB activity, which might have led to scavenging of photosynthetic and other excretion products normally respired by the aerobic bacteria (Bateson \& Ward 1988, Glud et al. 1992, Paerl et al. 1993). Previous studies postulated that the release of photosynthates may stimulate daytime sulfate-reduction (Fründ \& Cohen 1992, Canfield \& Des Marais 1993). Therefore, the decreasing trend in OCL and its uncoupling from GP could be explained by the inability of aerobic bacteria to compete for organics with SRB in the light.

Unlike in the photosynthetic zone, oxygen consumption in the non-photosynthetic zone showed an increasing trend with increasing temperature. Since sulfide accumulated at higher temperatures, it is likely that most of oxygen consumption in the nonphotosynthetic zone was due to sulfide oxidation. Sulfide-oxidizing bacteria outcompeted aerobic heterotrophs for oxygen at $45^{\circ} \mathrm{C}$, as suggested by the clear difference in areal rates of oxygen consumption in the photosynthetic and the non-photosynthetic zone. The OCL of phototrophs at $45^{\circ} \mathrm{C}$ was insignificant, since rates of NP and GP were close.

Areal rates of DR did not change significantly with increasing temperature, mainly because of restricted oxygen diffusion. Most dark oxygen consumption occurred in the top $0.5 \mathrm{~mm}$, probably by aerobic heterotrophic bacteria and sulfur-oxidizing bacteria (Canfield \& Des Marais 1993).

\section{Temperature and sulfur cycle}

Sulfate reduction was the most dominant process in the mat at high temperatures, while other processes (GP and OCL) were partially or completely inhibited. Thus, we presume that the SRB activity and the production of high sulfide concentrations had a greater influence than temperature on other mat processes. The increased rates of sulfate reduction with increasing temperature could be attributed to a hightemperature optimum for SRB and/or the increased availability of electron donors. On the other hand, the inactivation of sulfide oxidation at higher temperatures could result in the buildup of sulfide. Thermodynamic model calculations have shown that aerobic sulfur oxidation becomes energetically unfavorable near $50^{\circ} \mathrm{C}$ (McCollom \& Shock 1997). Since maximum sulfate reduction was detected at $50^{\circ} \mathrm{C}$, it is likely that these mats harbor moderately thermotolerant SRB. Sulfate reduction was apparently inhibited at $60^{\circ} \mathrm{C}$, and the measured sulfide was probably the remaining unoxidized sulfide from the $50^{\circ} \mathrm{C}$ incubation.

In the oxygen-sulfide overlapping zone, sulfide could be completely oxidized by oxygen to sulfate and/or elemental sulfur at temperatures below $50^{\circ} \mathrm{C}$ in both the light and dark, as deduced from the volumetric $\mathrm{O}_{2}$ and $\mathrm{S}_{\text {tot }}$ consumption rates. In contrast, at $50^{\circ} \mathrm{C}$ in the light and at $60^{\circ} \mathrm{C}$ in the light and dark, the amount of oxygen was insufficient for complete oxidation and this resulted in a leakage of sulfide into the overlying water. In the dark, maximum $\mathrm{S}_{\text {tot }}$ flux occurred in anoxic parts of the mat. Furthermore, a significant fraction of sulfide was removed before oxygen was reached, meaning that it must have been removed by other, anaerobic sulfide consumption processes. A close analysis revealed that the net sulfide consumption started at a depth corresponding to the oxygen penetration depth during the preceding light period. This suggests that this sulfide was possibly consumed by reactive iron species that accumulated in the mat during the oxic (light) periods (Wieland \& Kühl 2000a) and/or polysulfide formation. This scenario is feasible by assuming that part of oxygen consumption in the light is due to chemical oxidation of reduced compounds (e.g. FeS). This process leads to an accumulation of oxidized form of $\mathrm{Fe}$ that may form an efficient barrier against sulfide in the subsequent dark period, normally preventing sulfide from reaching the overlying water (Jørgensen 1994, Wieland et al. 2005). In addition to FeS precipitation, sulfide might also be removed by anoxygenic photosynthesis particularly at higher temperatures (Jørgensen et al. 1979). 


\section{Comparison with other mat systems}

In order to quantify the temperature sensitivity of different microbial processes and to allow a comparison with other mat systems, the apparent activation energy, $E_{\mathrm{a}}\left(\mathrm{kJ} \mathrm{mol}^{-1}\right)$ and $Q_{10}$ values in the range of 35 to $45^{\circ} \mathrm{C}$ were calculated according to Isaksen \& Jørgensen (1996). Interestingly, the $E_{\mathrm{a}}$ and the $Q_{10}$ values for the NP in our mat (47.8 and $1.9 \pm 0.08$, respectively) were comparable to those obtained for other mats regardless of their origin and field temperatures (see Table 1 in Pringault et al. 2001). However, the $E_{\mathrm{a}}$ and $Q_{10}$ values for the GP in our mat (22.2 and $1.33 \pm 0.03$, respectively) were considerably lower than those reported for other mats (e.g. 86 and 3.1 for the Solar Lake mat and 60 and 2.6 for the Antarctic mat, respectively) (Wieland \& Kühl 2000a,b, Pringault et al. 2001). This discrepancy can be explained if the OCL follows the opposite trend to temperature. Indeed the $Q_{10}$ for OCL in our mat was $0.9 \pm 0.008$ in a temperature range between 35 and $45^{\circ} \mathrm{C}$, and $0.4 \pm 0.3$ in a temperature range between 45 and $60^{\circ} \mathrm{C}(<1)$. This corresponds to temperature inhibition: a $Q_{10}$ of $>1$ was reported for the mats studied by Wieland \& Kühl (2000a,b) and Pringault et al. (2001), for which oxygen consumption in the light was also enhanced by temperature.

In conclusion, the temperature response of GP and sulfide production in our mat was comparable to that in mats from psychrophilic (Pringault et al. 2001) and mesophilic (Epping \& Kühl 2000, Wieland \& Kühl 2000a,b, Sørensen et al. 2004) environments. Among the differences were the unusually high sulfide concentrations in our mats, which were $\sim 9$ to 30 times higher than in their psychrophilic and mesophilic counterparts. The most unexpected difference was the uncoupling between OCL and GP with increasing temperature observed in our study. Our mat was apparently dominated by moderately thermotolerant microorganisms, since most processes were optimally performed at or above $45^{\circ} \mathrm{C}$.

Acknowledgements. We gratefully acknowledge Dr. W. Hamza for his support and hospitality during the field trip. G. Eickert, I. Schröder and K. Hohmann are especially thanked for constructing the microsensors and for their technical help. We also thank A. Gieseke and Nils Volkenborn for their help with calculations and statistical analysis. This research was financially supported by the Deutsche Forschungsgemeinschaft (grant BE 2167/4) and by the MaxPlanck Society.

\section{LITERATURE CITED}

Al-Thukair AA, Al-Hinai K (1993) Preliminary damage assessment of algal mats sites located in the Westen Gulf following the 1991 oil spill. Mar Pollut Bull 27:229-238
Bateson MM, Ward DM (1988) Photoexcretion and fate of glycolate in a hot spring cyanobacterial mat. Appl Environ Microbiol 54:1738-1743

Berg P, Risgaard-Petersen N, Rysgaard S (1998) Interpretation of measured concentration profiles in sediment pore water. Limnol Oceanogr 43:1500-1510

Buffan-Dubau E, Pringault O, de Wit R (2001) Artificial coldadapted microbial mats cultured from Antarctic lake samples. 1. Formation and structure. Aquat Microb Ecol 26:115-125

Canfield D, Des Marais DJ (1993) Biogeochemical cycles of carbon, sulfur, and free oxygen in a microbial mat. Geochim Cosmochim Acta 57:3971-3984

Castenholz RW (1976) The effect of sulfide on the blue green algae of hot springs. I. New Zealand and Iceland. J Phycol 12:54-68

Cline JD (1969) Spectrophotometric determination of hydrogen sulfide in natural waters. Limnol Oceanogr 14: $454-458$

Cohen Y, Jørgensen BB, Revsbech NP, Poplawski R (1986) Adaptation to hydrogen sulfide of oxygenic and anoxygenic photosynthesis among cyanobacteria. Appl Environ Microbiol 51:398-407

Davison IR (1991) Environmental effects on algal photosynthesis: temperature. J Phycol 27:2-8

Epping E, Kühl M (2000) The responses of photosynthesis and oxygen consumption to short-term changes in temperature and irradiance in a cyanobacterial mat (Ebro Delta, Spain). Environ Microbiol 2:465-474

Fonselius SH (1983) Determination of hydrogen sulphide. In: Grasshoff K, Ehrhardt M, Kremling K (eds) Methods of seawater analysis. Verlag Chemie, Weinheim, p 73-80

Fründ C, Cohen Y (1992) Diurnal cycles of sulfate reduction under oxic conditions in cyanobacterial mats. Appl Environ Microbiol 58:70-77

Garcia-Pichel F, Pringault O (2001) Cyanobacteria track water in desert soils. Nature 413

Glud RN, Ramsing B, Revsbech, NP (1992) Photosynthesis and photosynthesis coupled respiration in natural biofilms quantified with oxygen microsensors. J Phycol 28:51-60

Glud RN, Grundersen JK, Revsbech NP, Jørgensen BB (1994) Effects on the benthic diffusive boundary layer imposed by microelectrode. Limnol Oceanogr 39:462-467

Golubic S (1991) Microbial mats of Abu Dhabi. In: Margulis L, Olendzenski L (eds) Environmental evolution, effects of the origin and evolution of life on planet Earth. MIT Press, Cambridge, MA, p 131-147

Grasshoff K (1983) Determination of pH. In: Grasshof $\mathrm{K}$, Ehrhardt M, Kremling $\mathrm{K}$ (eds) Methods of seawater analysis. Verlag Chemie, Weinheim, p 85-97

Grötzschel S, Abed RMM, de Beer D (2002) Metabolic shifts in hypersaline microbial mats upon addition of organic substrates. Environ Microbiol 4:683-695

Isaksen MF, Jørgensen BB (1996) Adaptation of psychrophilic and psychrotrophic sulfate-reducing bacteria to permanently cold marine environments. Appl Environ Microbiol 62:408-414

Jensen J, Revsbech NP (1989) Photosynthesis and respiration of a diatom biofilm cultured in a new gradient growth chamber. FEMS Microbiol Ecol 62:29-38

Jeroschewski P, Steuckart C, Kühl M (1996) An amperometric microsensor for the determination of $\mathrm{H}_{2} \mathrm{~S}$ in aquatic environments. Anal Chem 68:4351-4357

Jørgensen BB (1994) Sulfate reduction and thiosulfate transformations in a cyanobacterial mat during a diel oxygen cycle. FEMS Microbiol Ecol 13:303-312 
Jørgensen BB, Revsbech NP (1985) Diffusive boundary layers and the oxygen uptake of sediments and detritus. Limnol Oceanogr 30:111-122

Jørgensen BB, Revsbech NP, Blackburn TH, Cohen Y (1979) Diurnal cycle of oxygen and sulfide microgradient and microbial photosynthesis in a cyanobacterial mat sediment. Appl Environ Microbiol 38:46-58

Jørgensen BB, Cohen Y, Revsbech NP (1983) Transition from anoxygenic to oxygenic photosynthesis in a Microcoleus chthonoplastes cyanobacterial mat. Appl Environ Microbiol 51:408-417

Jørgensen BB, Nelson DC, Ward DM (1992) Chemotrophy and decomposition in modern microbial mats. In: Schopf JW, Klein C (eds) The Proterozoic biosphere: a multidisciplinary study. Cambridge University Press, Cambridge, p 287-293

Kühl M, Glud RN, Plough H, Ramsing NB (1996) Microenvironmental control of photosynthesis and photosynthesis coupled respiration in an epilithic cyanobacterial biofilm. J Phycol 32:799-812

Kühl M, Steuckart C, Eickert G, Jeroschewski P (1998) A $\mathrm{H}_{2} \mathrm{~S}$ microsensor for profiling biofilms and sediments: application in an acidic lake sediment. Aquat Microb Ecol 15: 201-209

Li WKW, Smith JC, Platt T (1984) Temperature response of photosynthetic capacity and carboxylase activity in Arctic marine phytoplankton. Mar Ecol Prog Ser 17:237-243

McCollom TM, Shock EL (1997) Geochemical constraints on chemolithoautotrophic metabolism by microorganisms in seafloor hydrothermal systems. Geochim Cosmochim Acta 61:4375-4391

Millero FJ, Plese T, Fernandez M (1988) The dissociation of hydrogen-sulfide in seawater. Limnol Oceanogr 33: 269-274

Paerl HW, Bebout BM, Joye SB, Marais DJD (1993) Microscale characterization of dissolved organic matter production and uptake in marine microbial mat communities. Limnol Oceanogr 38:1150-1161

Pringault O, Buffan-Dubau E, Wit Rd (2001) Artificial coldadapted microbial mats cultured from Antarctic lake samples. 2. Short-term temperature effects on oxygen turnover. Aquat Microb Ecol 127:127-138

Raven JA, Geider RJ (1988) Temperature and algal growth. New Phytol 110:441-461

Revsbech NP (1989) An oxygen microelectrode with a guard cathode. Limnol Oceanogr 55:1907-1910

Revsbech NP, Jørgensen BB (1983) Photosynthesis of benthic microflora measured with high spatial resolution by the oxygen microprofile method: capabilities and limitations of the method. Limnol Oceanogr 28:749-756

Editorial responsibility: William K. W. Li,

Dartmouth, Nova Scotia, Canada
Revsbech NP, Jørgensen BB (1986) Microelectrodes: their use in microbial ecology. Adv Microb Ecol 9:293-352

Sherwood JE, Stagnitti F, Kokkinn MJ, Williams WD (1991) Dissolved oxygen concentrations in hypersaline waters. Limnol Oceanogr 36:235-250

Sørensen KB, Canfield DE, Oren A (2004) Salinity responses of benthic microbial communities in a solar saltern (Eilat, Israel). Appl Environ Microbiol 70:1608-1616

Stal LJ (1991) The metabolic versatility of the mat-building cyanobacteria Microcoleus chthonoplastes and Oscillatoria limosa and its ecological significance. Arch Hydrobiol Suppl 92:453-467

Sukenik A, Bennett J, Falkowski P (1987) Light-saturated photosynthesis limitation by electron transport or carbon fixation. Biochim Biophys Acta 891:205-215

Thamdrup B, Hansen JW, Jørgensen BB (1998) Temperature dependence of aerobic respiration in a coastal sediment. FEMS Microbiol Ecol 25:189-200

van den Ende FP, van Gemerden H (1994) Relationships between functional groups of organisms in microbial mats. In: Stal LJ, Caumette P (eds) Microbial mats. Berlin, Springer-Verlag, p 339-352

van den Ende FP, Laverman AM, van Gemerden H (1996) Coexistence of aerobic chemotrophic and anaerobic phototrophic sulfur bacteria under oxygen limitation. FEMS Microbiol Ecol 19:141-151

van Gemerden H (1993) Microbial mats-a joint venture. Mar Geol 113:3-25

Ward DM, Santegoeds CM, Nold SC, Ramsing NB, Ferris MJ, Bateson MM (1997) Biodiversity within hot spring microbial mat communities: molecular monitoring of enrichment cultures. Antonie Leeuwenhoek 71:143-150

Ward DM, Ferris MJ, Nold SC, Bateson MM (1998) A natural view of microbial biodiversity within hot spring cyanobacterial mat communities. Microbiol Mol Biol Rev 62: $1353-1370$

Wieland A, Kühl M (2000a) Short-term temperature effects on oxygen and sulfide cycling in a hypersaline cyanobacterial mat (Solar Lake, Egypt). Mar Ecol Prog Ser 196:87-102

Wieland A, Kühl M (2000b) Irradiance and temperature regulation of oxygenic photosynthesis and $\mathrm{O}_{2}$ consumption in a hypersaline cyanobacterial mat (Solar Lake, Egypt). Mar Biol 137:71-85

Wieland A, de Beer D, van Dusschoten D, Damgaard LR, Kühl M, van As H (2001) Fine scale measurement of diffusivity in a microbial mat with nuclear magnetic resonance imaging. Limnol Oceanogr 46:248-259

Wieland A, Zopfi J, Benthien M, Kühl M (2005) Biogeochemistry of an iron rich hypersaline microbial mat (Camargue, France). Microb Ecol 49:34-49

Submitted: January 23, 2006; Accepted: May 11, 2006

Proofs received from author(s): August 11, 2006 